gPRXM

Gurnal Profesi Kesehatan Masyanakat

http://jurnal.bhmm.ac.id/index.php/jpkm

${ }^{\square}$ Corresponding Author.

email address : nerserwin.08@gmail.com

Received : 2 Januari 2021 Revised : 5 Februari 2021 Accepted : 6 April 2021

\title{
Analisis Faktor yang Mempengaruhi Proses Berhenti Merokok pada Wanita Mantan Pecandu Rokok di Kabupaten Ngawi
}

\author{
$\square^{\square}$ Erwin Kurniasih \\ Akademi Keperawatan PemKab Ngawi, Indonesia
}

\begin{abstract}
ABSTRAK
Penelitian ini bertujuan untuk mengetahui faktor-faktor yang mempengaruhi proses berhenti merokok pada wanita mantan pecandu rokok. Jumlah perokok di kalangan wanita di Jawa Timur setiap tahunnya meningkat. Perilaku merokok bukanlah hal yang mudah dihentikan, terlebih lagi bagi perokok di Indonesia. Hasil survei yang dilakukan oleh LM3 menyebutkan bahwa dari 375 responden dinyatakan 66,2\% perokok pernah mencoba berhenti merokok tapi gagal. Penelitian ini merupakan penelitian kualitatif, dengan pendekatan grounded theory. Pengambilan data dilakukan kepada 10 responden wanita mantan pecandu rokok dengan metode wawancara mendalam. Analisis data dan codingyang digunakan pada penelitian in adalah triangulasi data yang dilakukan secara terus menerus sampai data yang didapat jenuh. Hasilnya adalah agarsebuah proses berhenti merokok dapat berhasil,diperlukan suatu dukungan dari diri sendiri maupun dari luar. Niat yang timbul dalam diri sendiri lebih besar daripada dukungan yang diberikan oleh keluarga dan teman-teman sebayanya. Niat yang muncul tersebut disebabkan oleh keinginan untuk melindungi janin yang ada di dalam kandungan (hamil) dan terjadi suatu hal yang membahayakan nyawanya (sakit).
\end{abstract}

Kata kunci: Mantan Pecandu Rokok, Rokok, Wanita

\section{PENDAHULUAN}

Berdasarkan Riset Kesehatan Dasar, perokok di Indonesia meningkat pada kelompok usia di atas 15 tahun, yaitu 34,2 persen (2007), 34,7 persen (2010), dan data yang terakhir mencapai 36,3 persen (2013). Adapun perokok wanita mengalami peningkatan dari 4,1 persen menjadi 6,7 persen pada tahun 2013. Diperkirakan sekitar 6,3 juta wanita di Indonesia yang aktif untuk merokok (Tribunnews.com). Pada tahun 2015, konsumsi rokok tertinggi adalah rokok kretek. Data menunjukkan jika proporsi perokok perempuan mencapai angka tertinggi 4,7\% di daerah Papua. Sedangkan perokok perempuan juga mulai tersebar dipulau jawa meliputi: DKI Jakarta dan Jawa barat sebesar 3\%. Dengan data yang ada telah menunjukkan bahwa perokok wanita mulai mengalami peningkatan (Riskesdas 2013, Badan Litbangkes, Kemenkes RI)
Menghentikan perilaku merokok bukanlah usaha mudah, terlebih lagi bagi perokok di Indonesia. Hasil survei yang dilakukan oleh LM3 (Lembaga Menanggulangi Masalah Merokok), dari 375 responden yang dinyatakan 66,2 persen perokok pernah mencoba berhenti merokok, tetapi mereka gagal. Kegagalan ini dikarenakan berbagai macam sebab; 42,9 persen tidak tau caranya; 25,7 persen sulit berkonsentrasi dan 2,9 persen terikat oleh sponsor rokok. Sementara itu, ada yang berhasil berhenti merokok disebabkan kesadaran sendiri (76 persen), sakit (16 persen), dan tuntutan profesi (8 persen) (Helman, 1994 dalam Ardini Ratih dan Hendriani Wiwin, 2012).

Faktor-faktor yang dapat mempengaruhi proses berhenti merokok antara lain: tekanan sakit fisik yang amat kuat dengan risiko tinggi (kematian) apabila tidak menghentikan perilaku merokoknya, melakukan perubahan

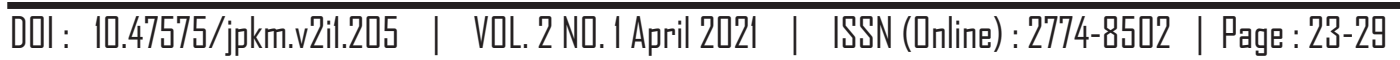


persepsi (dapat berkaitan dengan mitos seputar rokok), serta menyadarkan perokok melalui pengetahuan, dan evaluasi kerugian merokok dan keuntungan berhenti merokok (Syafiie R, dkk. 2009). Penelitian sebelumnya juga dilakukan di Surabaya yang menyatakan proses berhenti merokok pada setiap responden hampir sama yaitu mengurangi konsumsi rokok setiap harinya dan jika ingin merokok lebih maka responden menggantikannya dengan makan permen atau menyibukkan diri dengan pekerjaannya (Ardini Ratih dan Hendriani Wiwin, 2012).

Dari kasus di atas penelitian yang akan diambil oleh peneliti mengenai faktor-faktor yang mempengaruhi proses berhenti merokok pada mantan pecandu rokok di Kabupaten Ngawi. Dari penelitian yang akan dilaksanakan diharapkan membawa dampak yang baik untuk para wanita agar tidak menjadi perokok dengan berbagai pertimbangan yang ada. Dengan tujuan untuk mengetahui bagaimana dukungan orang-orang terdekat dalam melakukan proses berhenti merokok pada mantan pecandu rokok, mengetahui bagaimana niat wanita perokok dalam melaksanakan proses berhenti merokok, dan Mengetahui perilaku seorang wanita perokok yang melakukan proses berhenti merokok.

\section{METODE PENELITIAN}

Jenis penelitian yang dilakukan adalah studi dengan pendekatan grounded theory. Walaupun penelitian kualitatif memberikan deskripsi yang bersifat terurai, tetapi dari deskripsi tersebut diadakan abstraksi atau inferensi sehingga diperoleh kesimpulan-kesimpulan yang mendasar yang membentuk prinsip dasar, dalil, atau kaidah-kaidah. Kumpulan dari prinsip, dalil, atau kaidah tersebut berkenaan dengan sesuatu yang dapat menghasilkan teori baru, atau minimal memperkuat teori yang sudah ada (Mustari, 2012).

Penelitian ini menggunakan seluruh masyarakat Kabupaten Ngawi yang sudah menjadi mantan pecandu rokok sebagai populasinya.Waktu penelitian dilaksanakan pada bulan September-November 2020 Sedangkan, sampel dalam penelitian ini adalah orangorang yang memenuhi kriteria inklusi (mantan pecandu rokok wanita dengan rentang usia
20-35 tahun, telah berhenti merokok minimal 6 bulan saat dilaksanakannya penelitian. proses berhenti merokok dilakukan secara mandiri tanpa bantuan tenaga kesehatan atau tenaga medis, serta bersedia untuk menjadi responden),dan bersedia untuk menjadi responden dalam penelitian ini. Jumlah responden yang didapat adalah 10 orang dengan menggunakan tehnik snowball sampling.

Penelitian kualitatif sebagai human instrument, berfungsi menetapkan fokus penelitian, memilih informan sebagai sumber data, melakukan pengumpulan data, menilai kualitas data, analisis data, menafsirkan data dan membuat kesimpulan atas temuannya (Sugiyono, 2012). Sehingga, dalam penelitian ini, yang menjadi instrumen atau alat penelitian adalah peneliti itu sendiri dengan menggunakan kuesioner sebagai alat bantu untuk melaksanakan wawancara mendalam (in depth interview) dengan responden.

\section{HASIL DAN PEMBAHASAN}

Belum banyak masyarakat yang mengetahui bahwa di Kabupaten Ngawi telah ada wanita mantan pecandu rokok. Wanita mantan pecandu rokok di Kabupaten Ngawi sangat tertutup dan bahkan tidak mau untuk di publikasikan bahwa dirinya (wanita mantan pecandu rokok) ada disekitar wilayah Kabupaten Ngawi.

Dalam penelitian ini responden yang berhasil dikumpulkan dan telah memenuhi kriteria inklusi sebanyak 10 orang responden. Semua responden yang menyetujui untuk mengikuti penelitian ini tidak berkenan untuk menyebutkan namanya secara jelas sehingga, menggunakan inisial yang responden inginkan sendiri dan dua responden menginginkan suaranya untuk disamarkan. Semua responden yang berpartisipasi dalam penelitian ini berjenis kelamin perempuan dan berada di wilayah Kabupaten Ngawi.

Menghentikan kebiasaan merokok tidak selalu mudah dilakukan oleh setiap wanita. Alasan yang tepat sangat memengaruhi proses seorang wanita untuk melakukan suatu proses untuk menghentikan kebiasaannya. Hal-hal yang menjadi pertimbangan setiap wanita untuk berhenti merokok sangat beragam mulai dari usia yang sudah menua, menikah, hamil, dan sakit. 
Tabel 1

Karakteristik Subyek

\begin{tabular}{llc}
\hline No. & Karakteristik & Jumlah \\
\hline 1. & Umur & \\
& 21 tahun & 1 \\
23 tahun & 2 \\
& 25 tahun & 1 \\
29 tahun & 2 \\
& 30 tahun & 1 \\
& 33 tahun & 1 \\
& 35 tahun & 1 \\
& Pendidikan & \\
& SMP & 5 \\
& SMA & 2 \\
& Perguruan Tinggi & 3 \\
& Pekerjaan & 2 \\
3. & Pegawai Swasta & 5 \\
& Ibu Rumah Tangga & 2 \\
& Mahasiswa & 1 \\
& Wirausaha & 10 \\
\hline Jumlah Responden & &
\end{tabular}

Sumber: Data Primer Diolah, 2020

Seperti pada AR yang memiliki niat untuk berhenti merokok karena sakit, dan TM memiliki niatan untuk menghentikan kebiasaannya merokok karena menikah. Niat untuk berhenti merokok karena menikah ini dipertegas oleh RP yang mengaku bahwa kakaknya telah berjanji akan berhenti merokok karena akan menikah.

Tidak semua wanita mantan pecandu rokok mendapat dukungan dari keluarga maupun teman dekat saat akan menghentikan kebiasaan merokoknya. Keluarga dan teman tidak menjadi faktor pendukung yang utama, semuanya datang dari diri sendiri untuk melakukan proses berhenti merokok. Tujuh dari 10 orang responden tidak mendapat dukungan dari keluarga dikarenakan keluarga tidak mengetahui kebiasaan merokoknya, sedangkan teman hanya memberikan dukungan secara tersirat yang menyebabkan responden tidak mengetahui ada teman yang mendukungnya. AY mengungkapkan bahwa diri sendiri lah yang sangat berpengaruh terhadap kebaikan hidupnya. Keluarga tidak ada yang tau, jika ada keluarga yang tau maka AY akan terkena masalah sendiri, sedangkan teman hanya mengajak untuk senang-senang. Pengakuan AY dipertegas oleh satu temannya yang bernama MN. Keluarga tidak ada yang mendukung AY untuk berhenti merokok, karena keluarga tidak ada yang tau akan kebiasaan merokoknya. AY takut jika diketahui keluarganya, apalagi jika ibuknya mengetahui kebiasaan yang dia lakukan. Dukungan yang diberikan oleh teman kepada responden diutarakan dengan nada bercanda, sehingga responden mengira bahwa tidak ada dukungan sedikitpun dari temantemannya selama ini.

Pengakuan datang dari salah satu orang tua responden untuk kesksian bahwa tidak ada keluarga yang mengetahui kebiasaan seorang wanita merokok. NN berkata bahwa yang merokok di dalam rumahnya hanya dua orang laki-laki yaitu suami dan menantu laki-laki.

Tiga responden menyatakan bahwa keluarga mengetahui jika dia pernah mengkonsumsi rokok. Tiga responden menggaku, meskipun keluarga mengetahui kebiasaan merokoknya tapi tidak terlalu besar pengaruhnya untuk proses berhenti merokok. Ungkapan dari APR, kalau dari keluarga sebenarnya mensuport enggak tapi melarang pun mungkin udah capek, jadi ya gak ada tuntutan yang harus gimana cuman 
mengingatkan iya pasti dari mama, dari adek. suami sempet awalnya mengingatkan cuma lama-lama udah capek ngingetin. Pernyataan APR dipertegas oleh RI dengan ungkapan yang menyatakan bahwa suami tidak mau mempunya seorang istri perokok dan norma orang jawa itu kurang pas jika wanita merokok.

Seorang wanita perokok yang melakukan proses berhenti merokok secara langsung diakui oleh ketuju responden, sedangkan tiga orang yang lain menyatakan bahwa berhenti merokok melalui tahapan mengurangi rokok atau sesekali menggantikan dengan permen. Penyebab dari mereka bisa berhenti merokok karena hampir semua responden mengalami hamil dan langsung berhenti merokok secara langsung saat mengetahui bahwa dirinya sedang hamil. APR mengaku berhenti merokok karena dirinya sedang hamil, niat yang kuat ini muncul dari dalam dirinya sendiri karena dia merasa kasihan sama bayi yang ada di dalam kandungannya. APR berhenti merokok secara langsung, dia mendapatkan tekanan psikis seperti halnya suka main-main mulut. Pengakuan APR ini dipertegas oleh RI kembali, bahwa APR menghentikan kebiasaan merokok karena hamil.

Responden AR menghentikan kebiasaan merokoknya ini karena suatu kejadian yang pernah mengancam hidupnya dengan temanteman yang saat itu asyik pesta rokok semalaman diruangan tertutup. Semenjak kejadian itu AR berhenti merokok secara langsung dan tidak ingin mencoba rokok kembali.

MR menghentikan kebiasaan merokoknya secara bertahap dengan menggantikan konsumsi makanan yang manis-manis untuk menghindari rokok.

\section{PEMBAHASAN}

Sangat sulit menemukan wanita mantan pecandu rokok yang tinggal di kawasan kota Madiun. Wanita mantan pecandu rokok ini sangat tertutup kepada orang yang baru dikenal, dan hanya mau mengakui kebiasaan merokoknya kepada orang-orang tertentu. Dia tidak menginginkan ada orang lain yang mengetahui keberadaannya saat ini dengan kondisi yang dulunya pernah menjadi mantan pecandu rokok. Untuk mengetahui wanita mantan pecandu rokok ini perlu bantuan dari orang-orang terdekat wanita mantan pecandu rokok dan pengakuan secara tulus dari diri wanita mantan pecandu rokok itu sendiri kepada orang yang baru dia kenal. Wanita mantan pecandu rokok ini memiliki pendidikan yang sangat beragam mulai dari lulusan SMP, lulusan SMA, dan ada beberapa yang telah menyelesaikan pendidikannya di tingkat Perguruan Tinggi. Wanita mantan pecandu rokok ini ada yang bekerja sebagai pegawai swasta, ada juga yang hanya sebagai ibu rumah tangga, mahasiswa, hingga seorang wirausaha. Usia wanita mantan pecandu rokok berkisar antara 21 tahun hingga usia 35 tahun.

Niatan yang timbul untuk tidak merokok berawal dari perjanjian diri sendiri dengan suatu keadaan yang sedang dialami. Hal ini terjadi pada semua responden yang telah mengikuti penelitian ini. Satu responden mengalami sakit dan telah mendengarkan paparan riwayat penyakitnya dari dokter, dari kejadian itu dia mulai memiliki niat untuk menghentikan kebiasaan merokoknya. Responden belum menghentikan kebiasaanya karena masih banyak godaan dari teman-teman untuk merokok. Sedangkan, responden yang lainnya memiliki niatan untuk berhenti merokok karena telah menikah dan tidak ingin suami dan keluarga mengetahui kebiasaanya tersebut. Keluarga responden ada yang mengetahui kebiasaan merokoknya, responden ini tetap saja masih belum bisa menghentikan kebiasaanya meskipun telah berjanji sebelumnya.

Niat ditentukan oleh sikap, norma penting dalam masyarakat dan norma subjektif. Komponen pertama mengacu pada sikap terhadap perilaku. Sikap ini merupakan hasil pertimbangan untung dan rugi dari perilaku tersebut (outcome of behavior). Disamping itu juga dipertimbangkan pentingnya konsekuensi - konsekuensi yang akan terjadi bagi individu (evaluation regrading of the outcame) (Priyoto, 2014).

Keberhasilan berhenti merokok berbeda satu dengan yang lainnya, tergantung pada penyebab awal merokok, rentang waktu perokok, dosis rokok yang dihisap, dan kuatnya gejolak yang dialami. Dan bukan merupakan hal yang mudah untuk dapat berhenti merokok meski telah memiliki keinginan (Syafiie R, dkk. 2009). 
Meskipun seseorang telah mengetahui konsekuensi apa yang akan terjadi apabila tidak berhenti merokok dan apa konsekuensi saat telah memutuskan untuk berhenti merok, jika tidak ada niatan yang kuat dari diri sendiri tidak akan bisa berjalan sesuai dengan baik. Untuk menghentikan kebiasan merokok sangat dibutuhkan niat yang benar-benar kuat dari dalam diri sendiri. Niat akan berubah menjadi sebuah tindakan apabila dapat di dukung dengan lingkungan yang seharusnya tidak ada satu pun perokok disekitar orang yang akan menghentikan kebiasaan merokoknya.

Tidak semua perokok menunjukkan sikapnya kepada semua orang, walaupun itu keluarga ataupun suami. Hanya ada beberapa orang yang ingin terbuka dengan keluarga sehingga, dukungan yang datang saat ingin menghentikan kebiasaan merokok hanya dari dirinya sendiri. Ada keluarga yang mendukung untuk menghentikan kebiasaan merokok dengan cara mengirim berbagai artikel mengenai bahaya merokok melalui media sosial yang ada, selain itu juga melalui pembicaran sehari-hari yang dilakukan dirumah, dan mengingatkan bahwa seorang wanita nantinya akan hamil dan memiliki anak. Dukungan ini juga dari teman meskipun teman tidak menyampaikan secara serius terhadap responden yang akan menghentikan kebiasaan merokoknya.

Dorongan anggota keluarga, termasuk kawan terdekat juga mempengaruhi agar seseorang dapat menerima perilaku tertentu, yang kemudian diakui dengan saran, nasehat dan motivasi dari keluarga atu kawan. Kemampuan anggota keluarga atau kawan terdekat mempengaruhi seorang individu untuk berperilaku seperti yang mereka harapkan diperoleh dari pengalaman, pengetahuan dan penilaian individu tersebut terhadap perilaku tertentu dan keyakinan melihat keberhasilan orang lain berperilaku seperti yang disarankan (Priyoto, 2014).

Terbentuknya kesadaran bagi perokok yang ingin berhenti adalah keharusan jika ia ingin benar-benar berhenti. Maka setelah perokok benar-benar timbul kesadaran untuk berhenti, aksi atau tindakan kongkrit yang dilaluinya selayaknya mendapatkan sentuhan dimensi afeksi. Hal ini untuk memperkuat kemauan berhenti, agar diri dan peristiwa benar-benar terhubung dengan baik, dan agar menimbulkan jejak dalam memori yang mendalam, yang pada gilirannya memori tersebut memberi penguatan untuk terus berhenti merokok (Syafiie. R, 2009).

Teman dan keluarga yang mendukung untuk berhenti berokok hanyalah sebagai pendorong dalam diri seseorang, tetapi tidak bisa menjadikan alasan yang kuat untuk menghentikan kebiasaan merokoknya. Oleh sebab itu, hanya diri sendirilah yang mampu menumbuhkan niat untuk menghentikan kebiasaan merokok.

Seorang wanita dapat menghentikan kebiasaan merokoknya secara langsung tanpa ada suatu proses yang berarti. Meskipun telah mendapat larangan dari suami atau selalu bersama suami keinginan merokok pada seorang wanita tetap masih timbul. Keinginan untuk berhenti merokok tidak akan muncul lebih dalam jika belum ada suatu kejadian yang membuat hidup wanita merasa terancam atau untuk melindungi suatu kehidupan yang baru. Alasan yang diberikan sangat beragam dalam melakukan proses berhenti untuk mengkonsumsi rokok.

Berhenti merokok dikarenakan hamil adalah satu alasan yang diberikan karena ingin melindungi keadaan janin yang sedang di kandung. Seorang wanita akan berbuat segalanya asalkan bayi yang ada di dalam kandungannya tetap sehat. Selain itu yang bisa membuat seorang wanita berhenti merokok adalah suatu kejadian dimana kehidupannya sangat terancam dan dapat membunuhnya saat itu. Kejadian dimana seorang wanita mengalami keracunan karbon monoksida yang dihasilkan oleh asap rokok yang dihasilkan selama semalaman merokok diruangan tertutup. Suatu kejadian yang mengancam hidupnya itu akan selalu membuatnya berfikir untuk menjauhkan hidupnya dari rokok maupun asap rokok.

Wanita yang telah kecanduan dengan rokok akan susah untuk menghentikan kebiasaan merokoknya, meskipun bisa menghentikan merokok mereka akan melakukan dengan cara bertahap atau dengan cara mengganti dengan makanan yang manis. Permen juga menjadi andalan para wanita untuk menggantikan rokok yang selama ini mereka konsumsi. 
Praktek pertama yang harus dilakukan untuk menyukseskan program berhenti menghisap rokok adalah menetapkan niat, yaitu keyakinan dan kemauan ikrar dengan lisan. Hal ini sejalan dengan Hadis Nabi Muhammad SAW, "sesungguhnya, setiap amal perbuatan itu tergantung pada niatnya". Tanpa keyakinan dan kemauan hati yang kuat, kebanyakan mantan perokok akan terjerumus kembali pada kenikmatan menghisap rokok. Keyakinan dan kemauan hati dapat dipupuk secara bertahap dengan bantuan keluarga dan lingkungan pergaulan yang sehat (Satiti Alfi, 2011).

Berhenti merokok merupakan suatu dunia tersendiri, dunia yang memberikan pengalaman penuh subjektifitas, karena merokok juga merupakan suatu dunia tersendiri. Para pecandu rokok (smoker) yang berhasil untuk berhenti memiliki pengalaman yang berbedabeda walaupun mereka hidup dalam dunia yang sama. Menurut para eksistensialis (Abidin, dalam Syafiie. R, 2009), eksistensi adalah milik pribadi, tidak ada dua individu yang identik dan tidak ada pula dua pengalaman yang identik, begitu juga dengan pengalaman dalam proses yang dilalui oleh mantan pecandu rokok. Mereka memiliki pengalaman yang berbedabeda dan bersifat subjektif.

Niatan untuk berhenti merokok hanya dapat keluar dari diri seseorang dengan didukung oleh suatu kejadian yang akan membuat hidupnya menjadi lebih berarti jika memulai untuk berhenti merokok. Keluarga, sahabat, dan lingkungan hanya untuk penyeimbang dalam mengambil sebuah keputusan yang akan dijalani oleh seseorang.

\section{SIMPULAN}

Dalam suatu proses untuk melakukan berhenti merokok diperlukan suatu dukungan dari dalam diri sendiri maupun dari luar. Dukungan yang berasal dari dalam diri sangat besar pengaruhnya terhadap perubahan suatu tindakan agar menjadi yang lebih baik. Dukungan keluarga hanya menjadi pemicu untuk melanjutkan niatan berhenti merokok bagi seorang wanita perokok, bukan untuk menjadi faktor penghentian konsumsi rokok. Sedangkan teman dekat memberikan dukungan dalam bentuk yang tersamarkan, teman akan memberikan semua keputasan untuk berhenti merokok padanya tanpa mengganggu keputusan yang telah diambil. Niat seseorang dalam melakukan proses berhenti merokok dipengaruhi oleh beberapa hal seperti: larangan yang diberikan oleh pacar atau suami, sakit, memikirkan masa depan, dan hamil. Niat jika tidak ada tindakan dari seseorang akan berlalu begitu saja. Niat semakin lama harus diperkuat dengan adanya dukungan dan tindakan yang pasti. Dalam melakukan perubahan perilaku tidak bisa dilakukan dalam waktu yang instan. Meskipun telah memiliki niat para wanita perokok ini masih tetap mengkonsumsi dengan batasan yang mereka tentukan sendiri. Bagi seorang wanita perokok, untuk menghentikan kebiasaan merokoknya harus ada alasan kuat yang timbul dari dalam diri sendiri. Alasan yang memicu wanita perokok untuk menghentikan kebiasaan konsumsi rokok dikarenakan adanya suatu kejadian yang mengancam hidupnya (sakit) dan pada saat melindungi hidup orang lain (janin yang ada di dalam kandungan).

\section{DAFTAR PUSTAKA}

Adi Sukarno, P. 2014. Jumlah Perokok Terus Meningkat, Indonesia Tertinggi Kedua di Dunia. Jakarta. Tersedia dalam: http://m.bisnis.com/lifestyle/ $\mathrm{read} / 20140601 / 220 / 232021 / \mathrm{jumlah}-$ perokok-terus-meningkat-indonesiatertinggi-kedua-di-dunia (diakses pada: 7 Mei 2016).

Admin. 2015. Jumlah perokok Wanita dan Anak Di Jawa Timur Meningkat Tiap Tahunnya. Tersedia dalam: http://primaradio.co.id/3685/jumlahperokok-wanita-dan-anak-di-jawatimur-meningkat-tiap-tahunnya.html (diakses pada: 7 Mei 2016).

Ardini Ratih \& Hendriani Wiwin. 2012. Proses Berhenti Merokok Secara Mandiri Pada Mantan Pecandu Rokok Dalam Usia Dewasa Awal. Tersedia dalam: http://journal.unair.ac.id/ filerPDF/110511160_2v.pdf(diakses pada: 20 Oktober 2015).

Handayani, Abni. 2012. Perempuan Berbicara Kretek. Jakarta: Indonesia Berdikari. 
Jaya, Muhammad. 2009. Pembunuh Berbahaya Itu Bernama Rokok. Yogyakarta: Riz'ma.

Litbang Kemenkes. 2015. Permasalahan Konsumsi Rokok di Indonesia. Tersedia dalam: http://www.litbang.kemkes. go.id/permasalahan-konsumsi-rokok-diindonesia/ (diakses pada: 24 Desember 2015).

Litbang Kemenkes. 2015. Tiga Fakta Rokok dan Tembakau di Indonesia. Tersedia dalam: http://www.litbang.kemkes. go.id/tiga-fakta-rokok-dan-tembakaudi-indonesia/ (diakses pada: 24 Desember 2015).

Martini, Sih. 2014. Makna Merokok pada Remaja Putri Perokok. Surabaya: Universitas Airlangga. Tersedia dalam: http://journal.unair.ac.id/maknamerokok-pada-remaja-putri-perokokarticle-7570-media-53-category-10.html (diakses pada: 31 Januari 2016).

Mintangtono, Hari. 2007. Tetapkan Kawasan Tanpa Rokok. Madiun : Radar Madiun. Tersedia dalam: https:// www.mailarchive.com/madiunclub@ y ahoogroups.com/msg 13180 . html(diakses pada: 14 Mei 2016).

Murti, Bhisma. 2010. Desain dan Ukuran Sampel untuk Penelitian Kuantitatif dan Kualitatif di Bidang Kesehatan. Yogyakarta: Gadjah Mada University Press.

Mustari, Mohamad. 2012. Pengantar Metode Penelitian. Yogyakarta: Laksbang Pressindo.
Notoatmodjo, Soekidjo. 2010. Ilmu Perilaku Kesehatan. Jakarta : Rineka Cipta.

Notoatmodjo, Soekidjo. 2012. Metodologi Penelitian Kesehatan. Jakarta : Rineka Cipta.

Pradeep Lele Pallavi. 2014. Effectiveness of Planned Teaching on Early Signs and Symptoms and Immediate Treatment of Myocardial Infarction in Among Patients. Mumbai (India). Tersedia dalam: http://www.ijsr.net/archive/v3i6/ MDIwMTMxOTMz.pdf(diakses pada: 20 November 2015).

Priyoto. 2014. Teori Sikap \& Perilaku dalam Kesehatan. Yogyakarta : Nuha Medika

Proverawati, Atikah \& Rahmawati, Eni. 2012. PHBS Perilaku Hidup Bersih \& Sehat. Yogyakarta : Nuha Medika.

Satiti, Alfi. 2011. Strategi Rahasia Berhenti Merokok. Jakarta : Datamedia.

Sugiyono. 2012. Metode Penelitian Kuantitatif Kualitatif dan $R \& D$. Bandung : Alfabeta.

Supardi, Sudibyo dan Surahman. 2014. Metode Penelitian untuk Mahasiswa Farmasi. Jakarta : CV. Trans Info Media.

Syafie R, dkk. 2009. Stop smoking :studi kualitatif terhadap pengalaman mantan pecandu rokok dalam menghentikan kebiasaannya. Semarang : Universitas Diponegoro. Tersedia dalam: http:// www.Eprints.undip.ac.id/10932 (diakses pada: 31 Januari 2016). 